\title{
Effect of Partial Replacement of Slag and Nano Silica Infused Slag on Properties of Concrete
}

\author{
Prakash Mallappa Munnoli', Tejashwini R. Pattar², Jyoti S. Garawad ${ }^{3}$ \\ 1,2,3S D M College of Engineering and Technology, Dharwad. \\ E-mail: munnolipm@gmail.com \\ Published Online: June 28, 2017 \\ The Author(s) 2017. This article is published with open access at www.chitkara.edu.in/publications
}

Abstract: Investigations were carried out on the changes in properties of concrete when steel slag is used in concrete in its normal form and after modifying its properties by infusing it with nano silica. The sand is replaced by steel slag and modified steel slag by $10 \%, 20 \%$ and $30 \%$ in M30 grade concrete. Tests results on compressive strength and workability of concrete revealed that, compressive strength of concrete cubes after 28 days increased by $25.4 \%, 26.4 \%$ and $45.2 \%$ for $10 \%, 20 \%$ and $30 \%$ respectively after replacing sand by steel slag. After modification of steel slag properties by infusing it with nano silica, the 28 days compressive strength was observed to be increased by $38.19 \%, 35.80 \%$ and $27.89 \%$ for $10 \%, 20 \%$ and $30 \%$ as compared to traditional concrete mix respectively after replacement. Infusing steel slag with nano silica increased the compressive strength of concrete mix by $20.17 \%, 25.74 \%$ and $49.64 \%$ for $10 \%, 20 \%$ and $30 \%$ respectively when compared to normal steel slag concrete mix. It was also observed that using steel slag in concrete mix also influences on water consumption in concrete mix. Workability tests conducted using 0.45 and $0.5 \mathrm{w} / \mathrm{c}$ ratio and the inference was that the workability increased with the increase in percentage of steel slag but workability decreases with the increase in percentage of modified steel slag.

Abbreviations: CS: Compressive strength, NS: Nano silica, INSS: Infused Nano Silica Steel slag, FA: Fine aggregate, CA: Coarse aggregate, PSD: Particle size distribution, TC: Traditional concrete, SSC: Steel slag concrete,

Keywords: Specific gravity, Compressive strength, Infusion, Nano silica, steel slag, workability, Particle size distribution

\section{INTRODUCTION}

Concrete is the main heterogeneous composite material used in construction industry, whose main ingredients are cement, FA, CA, water. FA and CA are derived from natural resources which are depleting at a alarming rate due to infrastructure projects. Therefore searching for alternatives for natural aggregates is significantly gaining momentum all over the world. Industrial
Journal on Today's Ideas Tomorrow's Technologies, Vol. 5, No. 1, June 2017 pp. 64-75

CHITKARA 司 UNIVERSITY 
solid wastes with moderate to high specific gravity are considered to be useful in making concrete.

The utilization of solid wastes in construction at low cost and reducing load on natural resources is one of the innovative ideas globally accepted (P. Ziemkiewicz 1998; Singh, S.P. et al., 2013) for sustainable development. Globally, the estimated quantity of solid wastes generation was 12 billion tons in the year 2002 (Pappu et al., 2007). Among this amount, 11 billion tons were industrial solid wastes and 1.6 billion tons were municipal solid wastes and likely to touch $19 \mathrm{BTY}^{-1}$ by 2025 (Yoshizawa et al., 2004). Asia contribute $4.4 \mathrm{BTY}^{-1}$ of solid wastes with $6 \%$ share from India (Yoshizawa et al., 2004; CPCB, 2000) and Malaysia contributes $150000 \mathrm{TD}^{-1}$. The disposal of these wastes has become a major environmental problem in Malaysia and thus the possibility of recycling the solid wastes for use in construction materials is of increasing importance. (Pappu et al.,2007). Similarly, the recycling of hazardous wastes for use in construction materials and the environmental impact of such practices have been studied for many years (Cyr et al., 2004). Steel slag (SS) is one of such solid wastes (Caijun Shi 2004), the average SS generated data on plant wise in 2009-10 and 2010-11 are given in Table 1. SS finds application in various construction activities Table 2 which is a by product of steel industry. For bulk concrete uses, like large foundations, high density concrete (nuclear applications) and marine structures, SS has some merit. When considering SS for structural concrete applications, special care must be taken to confirm that the aggregate is totally stable, and that the Alkali Silica Reaction potential is within specified limits. SS has been used extensively around the world as: railway ballast, trickling filter bed media, pipe bedding, water course protection, land reclamation, bulk fill embankments and gabion stone. (Kevin A. H 1996, J.W. Lim et al 2016).

From the literature survey we have envisaged that there is significant application of SS in civil engineering applications. Whereas further use of SS by infusing with NS is yet to be studied using pin point experiments.

Therefore the present study involves experimental investigations on properties of concrete by using of SS and NS infused SS as a partial replacement to FA.

\section{MATERIALS AND METHODS}

\section{Procurement of research material}

- Steel slag was procured from Karthik Inductions; Rukmini \& Rama (RR) steels Pvt. Ltd., Kundaim Industrial Estate. Goa (Plate 1).
Effect of Partial Replacement of Slag and Nano Silica Infused Slag on Properties of Concrete 
Munnoli, P. M Pattar, T. R. Garawad, J. S.

- Nano silica was procured from ASTRRA chemicals, Chennai, India (Plate 2).

- CA, FA, Cement were procured from locally available dealers and maintained in the civil engineering laboratory.

Specific Gravity test was conducted as per IS: 2386 (Part III \& IV) - 1963 The Particle size distribution of SS, and infused SS was obtained by running sieve analysis as per IS 2720 (part IV) -1985.

\section{Infusion process:}

The experimental set up consists of beakers of Size $500 \mathrm{ml}$ were taken and in each $200 \mathrm{~g}$ of SS was taken and varied proportions of NS was added to each beaker and water of $85 \mathrm{ml}$ and the set up as preserved for 3 days. The INSS is placed in Plate 3.

Preparing the M30 concrete with SS and INSS and carrying out CS experiments.

\section{Concrete Mix design for M 30 grade concrete}

The Mix design was carried out in accordance with IS 10262-2009 with water cement ratio of 0.5 .

Standard concrete cubes of size 150 x 150 x 150 were prepared.

Workability test was carried out in accordance with IS 1199 - 1959 curing of cubes was carried out in a water tank temporarily built water tank specially constructed using a polythene placed inside the used concrete cube wall constructed in a rectangular fashion of size $2 \mathrm{~m} \times 1 \mathrm{~m} \times 1 \mathrm{~m}$ depth.

The CS was determined out using a universal testing machine in accordance with IS 516:1959. The results are tabulated and placed in results and discussed for the comparison with other researchers.

\section{RESULTS AND DISCUSSION}

The results of proportions of SS : WATER : NS are place in Table 4

The comparison of specific gravity of the materials indicates that the SS well fits as a material to be replaced in the concrete as FA and CA..

PSD of the FA and crushed SS passing through the $4.75 \mathrm{~mm}$ sieve tested were confirming to zone II of IS code 383-1970. Which is most favourable for concrete making. The PDS of FA and SS is placed in Fig.1

The workability test indicates that as the percentage of SS increases the slump value increases. The slump value for SSC is nearly same as TC at $10 \%$ replacement and gradually increases for $20 \%$ and $30 \%$. The changes are consistent for w/c 0.5 but there is increase in workability Fig 2 . The results are in line with Pofale A D and Mohammed N (2012).

The compaction factor result indicates that the compaction factor increases with increase in percentage of SS in concrete. The graph also indicates that at 
w/c ratio 0.45 workability is medium and at w/c 0.5 workability is high Fig 3.

From the Comparison of slump values for TC and modified SS in concrete placed in fig 4 . it can be observed that as the percentage of INSS as FA increases the workability for $10 \%$ compared to TC but decreases for $20 \%$ and $30 \%$ compared to $10 \%$ but increased when compared to TC for both 0.45 and $0.5 \mathrm{w} / \mathrm{c}$ ratio. Higher workability obtained at 0.5 compared to $0.45 \mathrm{w} / \mathrm{c}$ ratios.

Compaction factor increases with increase in INSS percentage in concrete compared to $\mathrm{TC}$ but comparing to $10 \%$ replacement the compaction factor decreases for 20\% and $30 \%$ replacement Fig 5.From the graphs obtained for slump and compaction factor for different mixes of concrete with SS and INSS, it can be inferred that the workability reduces as the percentage of INSS increases in the concrete mix, and the workability increases as the normal SS percentage of replacement increased.

It can be inferred from Fig. 6 that as the percentage replacement of SS increase in concrete as FA the compressive strength of concrete is increasing. Further trial mixes to be carried out to know the CS after complete replacement of FA by SS results in line with Khalid Raza, et al (2014).

Replacing INSS in concrete increased the strength in concrete upto $10 \%$ replacement of FA but further the CS decreased Fig.7.

The comparison of CS of SSC and INSS concrete with TC mixes Fig 8. The CS of both mixes has increased compared to TC. CS of SSC mix is higher than that of INSS mix. CS of 30\% replacement of FA by SS in concrete has obtained highest strength at the end of 28 days. From the graph it can be inferred that replacing not more than $10 \%$ of infused SS is favourable and not more than that. Gurjeet Singh, et al 2015 has replaced with 100\% SS and have got results in confirmity with us.

\section{CONCLUSION}

From our research work we conclude the following:

- Using steel slag as fine aggregate increases the strength in concrete by $25.4 \%, 26.4 \%$ and $45.29 \%$ for 10,20 and 30 percent respectively after 28 days of curing

- After infusing SS with nano silica $\left(\mathrm{SiO}_{2}\right.$ ) strength of concrete was observed to be increased by $38.19 \%, 35.80 \%$ and $27.89 \%$ for 10,20 and 30 respectively after 28 days of curing.

\section{REFERENCES}

1. Annual Review Report Prepared in compliance to the provision 8(2) of the MSW Rules, 2000). Central Pollution Control Board MOEF Consolidated

2. Chong K, P and Garboczi E, J "Smart and Designer Structural Material Systems",Progress in Structural Engineering and Materials (2002), Vol.4, p. 417-430.
Effect of Partial Replacement of Slag and Nano Silica Infused Slag on Properties of Concrete 
Munnoli, P. M Pattar, T. R. Garawad, J. S.
3. Devanoor A and Nagakumar M S (2014), Studies On Soil Stabilization Using Blast Furnace Slag, International Journal Of Advanced Engineering and Research and Technology, ISSN No 2348 - 8190 Pg No 61 - 65

4. Firoozi A A, Taha M R, Firoozi A A, (2014), Nanotechnology in Civil Engineering, EJGE vol 19, Bund T.

5. Fistric M, Strineka A, Roskovic R, (2010) Properties Of Steel Slag Aggregate And Steel Slag Asphalt Institute IGH Laboratory IGH, Zagrab Croatia pp1358 - 1366.

6. Gurjeet Singh*, Sanjay Sangwan, Mohd. Usman (2015) Experimental Study Of Blast Furnace Slag Concrete, International Journal Of Engineering Sciences \& Research Technology , ISSN: 2277-9655 (I2OR), Publication Impact Factor: 3.785

7. Indian Minerals Yearbook 2014 (Part- II : Metals \& Alloys) 53rd Edition slag-iron and steel (final release) government of India ministry of mines Indian bureau of mines Indira Bhavan, Civil Lines,NAGPUR pp 71-1 to 71-8.

8. Jaglan H, Mital A, (2015) Review On Stabilization Of Soil By Steel Industry Waste IJRREST International Journal Of Research Review In Engineering Science \& Technology (Issn 2278-6643) pages 228-230.

9. Kavak A and Bilgen G (2016) Reuse of Ground Granulated Blast Furnace Slag (GGBFS) in Lime Stabilized Embankment Materials IACSIT International Journal of Engineering and Technology pp 11-14.

10. Kevin A. Holliday (1996) ,Steel Slag - The High Performance Industrial Aggregate Steel world 1997, 2, 11-14.

11. Khalid R, Sharda S, Ritesh M, Patel, R, D, (2014) Comparative Strength Analysis of Concrete by Using Steel Slag as an Alternative to Normal Aggregates (Coarse) in Concrete International Journal of Computer \& Mathematical Sciences 3(5). p 53-57.

12. Khan Z A, Rezqallah H M, Khalaf A. Al-Ofi, and Khan N, (2002) Review of steel slag utilization in saudi Arabia. The 6th Saudi Engineering Conference, KFUPM, Dhahran, December pp 369-382.

13. Koranne S S , Valunjkar S S, (2015), Utilization Of Steel Slag In Roads Of Marathawada Region, International Journal Of Innovations In Engineering Research And Technology, 2(7) $1-7$.

14. Lim J.W. Chew L., Thomas S.Y. Choong, T C and M.H. Yazdi, (2016), Overview of Steel Slag Application and Utilization, MATEC Web of Conferences 74, 00026 (2016), DOI: 10.1051/matecconf/20167400026

15. Liqian Qia, Jiaxiang Liua*, Qian Liua (2015) Compound Effect of $\mathrm{CaCO} 3$ and $\mathrm{CaSO} 4 \cdot 2 \mathrm{H} 2$ O on the Strength of Steel Slag - Cement Binding Materials, Received: July 4, 2015; Revised: October 10, 2015; Accepted: November 20, 2015, Materials Research. 2016; 19(2): 269-275 DOI: http://dx.doi.org/10.1590/1980-5373-MR-2015-0387

16. Mahmoud A, (2012) Evaluation of the use of steel slag in Concrete,ARRB Conference Shaping the future: Linking policy, research and outcomes, Perth, Australia, pp 1-9

17. Md. Safiuddin, MohdZamin Jumaat, M. A. Salam, M. S. Islam and R. H,(2010), Utilization of solid wastes in construction materials, International Journal of the Physical Sciences Vol. 5(13), pp. 1952-1963.

18. Monosi S, Ruello M L, Sani D, (2015) Electric arc furnace slag as natural aggregate replacement in concrete Production Universit_a Politecnica delle Marche, Ancona, pp 66-72.

19. Oluwasolaa E A, Mohd Rosli Hainina,b*, Md. Maniruzzaman A. Azizacv (2014) Characteristics and Utilization of Steel Slag in Road Construction Jurnal Teknologi. pp 117-123.

20. Pappu A, Saxena M, Asolekar SR (2007). Solid Wastes Generation inIndia and their Recycling Potential in Building Materials. Building and Environment, 42:2311-2320. pp 2311-2320

21. Patel A S, Rathod H A, Sharma N D (2013), An Overview on Application of Nanotechnology in Construction Industry, International Journal of Innovative Research in Science, Engineer- 
ing and Technology, PP 6094 TO 6098 2(11) ISSN: 2319-8753.

22. Patil S, Bachhav S, Kshirsagar, D, Y (2016) Use of steel slag in construction of flexible pavement International Journal of Engineering and Innovative Technology (IJEIT) pp 24-27

23. Pofale A D Mohammed N (2012) Experimental investigation of using slag as an alternative to normal aggregates (coarse and fine) in concrete (ISSN 0976 - 4399). pp 117-127.

24. Shi C, (2004) Steel Slag-Its Production, Processing, Characteristics and Cementitious Properties Journal Of Materials In Civil Engineering (C) Asce, J. Mater. Civ. Eng., 2004, 16(3): 230-236.

25. Singh, S.P.1 and Murmu, M. (2013) Eco-friendly concrete using by-products of Steel industry Department of Civil Engineering, National Institute of Technology, Rourkela-769008, Orissa, India. https://www.scribd.com/document/102003387/Eco-Journal, 1-14.

26. Srivastava A, Singh K (2011) Nanotechnology In Civil Engineering And Construction: A Review on State of the Art and Future Prospects, Proceedings of Indian Geotechnical Conference December 15-17, 2011, Kochi (Paper No.R-024).

27. Steel Slag - Material Description - User Guidelines for Waste and By product Materials in Pavement Construction - FHWA-RD-97-148.

28. Taylor M, (2006) An Assessment of Iron and Steel Slag for treatment of Storm water Pollution. Landcare Research Private Bag, 3127 Hamilton.

29. Yildirim, I. Z., M. Prezzi, M. Vasudevan, and H. Santoso (2013). Use of Soil-Steel SlagClass-C Fly Ash Mixtures in Subgrade Applications. Publication FHWA/IN/JTRP-2013/06. Joint Transportation Research Program, Indiana Department of Transportation and Purdue University, West Lafayette, Indiana,. doi: 10.5703/1288284315188.

30. Yoshizawa S, Tanaka M, Shekdar AV (2004). Global Trends in Waste Generation. In Recycling, Waste Treatment and Clean Technology,TMS Mineral, Metals and Materials Publishers. pp : $1259-1264$.

31. Zeghichi L, (2006) "The Effect of Replacement of Naturals Aggregates by Slag Products on the Strength of Concrete, "Asian Journal of Civil Engineering (Building and Housing),Vol. 7,2006, pp.27-35.

32. Ziemkiewicz P. (1992) National Mine Land Reclamation Center, West Virginia University, Box 6064, Morgantown, WV 26505-6064. pp 44-62.

Table 1: Plant wise Average Generation of Slag in 2009-10 and 2010-11 in India.

\begin{tabular}{|l|l|l|}
\hline Steel plant & $\begin{array}{l}\text { Production in year } \\
\text { (n kg/aud of hot } \\
\text { metal) }\end{array}$ & $\begin{array}{l}\text { Production in } \\
\text { year } \\
\text { (In kg/aud of hot } \\
\text { metal) }\end{array}$ \\
\hline Bhilai Steel Plant, Durg, Chhattisgarh. & 395 & 399 \\
\hline Bokaro Steel Plant Bokaro, Jharkhand & 380 & $370-380$ \\
\hline Rourkela Steel Plant, Rourkela, Odisha & NA & NA \\
\hline $\begin{array}{l}\text { Visvesvaraya Iron \& Steel Plant, Bhadra- } \\
\text { vati, Karnataka. }\end{array}$ & 318 & NA \\
\hline $\begin{array}{l}\text { Durgapur Steel Plant, Durgapur, West Ben- } \\
\text { gal. }\end{array}$ & NA & NA \\
\hline IISCO Steel Plant, Burnpur, West Bengal. & 503 & NA \\
\hline $\begin{array}{l}\text { IDCOL Kalinga Iron Works Ltd, Barbil, } \\
\text { Odisha. }\end{array}$ & NA & 0.380 \\
\hline
\end{tabular}

Effect of Partial Replacement of Slag and Nano Silica Infused Slag on Properties of Concrete 
Munnoli, P. M

Pattar, T. R.

Garawad, J. S.

\begin{tabular}{|l|l|l|}
\hline JSW Steel Ltd, Bellary, Karnataka & NA & NA \\
\hline $\begin{array}{l}\text { NeelachalIspat Nigam Ltd. Kalingnagar, } \\
\text { Duburi, Odisha }\end{array}$ & 273 & 287 \\
\hline $\begin{array}{l}\text { RashtriyaIspat Nigam Ltd, Visakhapat- } \\
\text { nam, Andhra Pradesh. }\end{array}$ & 310 & 320 \\
\hline Tata Steel Ltd, Jamshedpur, Jharkhand & 279 & 274 \\
\hline VISA Steel Ltd. Kalingnagar,Odisha. & 16 & NA \\
\hline
\end{tabular}

Following table gives utilization of SS in construction industry in various countries.

Table 2: Country wise application of SS in construction industry

\begin{tabular}{|l|l|l|}
\hline Country & $\begin{array}{l}\text { Applications of SS in construction in- } \\
\text { dustry }\end{array}$ & Reference \\
\hline Malaysia & Road; Cement ;Rail Ballast; Bridge & $\begin{array}{l}\text { Oluwasolaa, et al 2014, } \\
\text { Patil S et al 2016 }\end{array}$ \\
\hline Turkey & Road materials; Lime stabilization & Kavak A et al 2016 \\
\hline India & Replacement of CA; & Khalid R, et al 2014, \\
\hline & Embankments; Flexible pavements & Patil S S, et al, 2016 \\
\hline & Sub grade pavements & Yildirim I Z et al 2009 \\
\hline & $\begin{array}{l}\text { Fertilizers, hydraulic engineering, metal- } \\
\text { lurgical purpose }\end{array}$ & $\begin{array}{l}\text { Singh S P and Murmu } \\
\text { M }\end{array}$ \\
\hline $\begin{array}{l}\text { Soudi Ara- } \\
\text { bia }\end{array}$ & Sub base pavements & Khan et al 2002 \\
\hline New Zeland & Removal of storm water contaminants & Taylor M 2006 \\
\hline China & Cement & Liqian Qi et al 2015 \\
\hline Italy & Replacement of CA in concrete & $\begin{array}{l}\text { Monosi S, et al ()Md. } \\
\text { Safiuddin 2010, Mah- } \\
\text { moud A, 2012 }\end{array}$ \\
\hline
\end{tabular}

Table 3: Applications of nanotechnology in construction industry

\begin{tabular}{|l|l|l|}
\hline India & $\begin{array}{l}\text { concrete for reducing segregation in } \\
\text { self compacted concrete, }\end{array}$ & $\begin{array}{l}\text { Patel Abhiyan } \\
\text { S et.al (2013) }\end{array}$ \\
\hline $\begin{array}{l}\text { The use of copper nano-particles in low carbon HPS } \\
\text { is remarkable, The use of nano sensors in construction } \\
\text { phase to know the early age properties of concrete is very } \\
\text { useful, Its use in water purification system by replacing } \\
\text { the use of granulated particles of carbon in filtration with } \\
\text { purifiers like Nano Ceram-Pac (NCP). }\end{array}$ & $\begin{array}{l}\text { Amit Srivas- } \\
\text { tava, Kirti } \\
\text { Singh (2011) }\end{array}$ \\
\hline
\end{tabular}




\begin{tabular}{|l|l|l|}
\hline Nano cement, Nano composites & Ali Akbar \\
& Firoozi, Mohd \\
& Raihan Taha, \\
Ali Asghar \\
Firoozi, (2014)
\end{tabular}

Table 4: Proportions of SS : WATER : NS

\begin{tabular}{|c|c|c|}
\hline SS (grams) & Water $(\mathbf{m l})$ & NS (grams) \\
\hline 200 & 85 & 0.2 \\
\hline 200 & 85 & 0.4 \\
\hline 200 & 85 & 0.6 \\
\hline 200 & 85 & 0.8 \\
\hline 200 & 85 & 1.0 \\
\hline
\end{tabular}

Table 5: Properties of ingredients used in concrete

\begin{tabular}{|l|c|c|c|c|}
\hline Material & Specific gravity & $\begin{array}{c}\text { Normal con- } \\
\text { sistency }\end{array}$ & Fineness index & Sieve analysis \\
\hline Cement & 3.16 & $35 \%$ & 2 & NA \\
\hline FA & 2.774 & NA & NA & Zone II \\
\hline CA & 2.763 & NA & NA & NA \\
\hline SS & 2.36 & NA & NA & NA \\
\hline NS & 1.35 & NA & NA & NA \\
\hline INSS* & 4.3 & NA & NA & Zone II \\
\hline
\end{tabular}

*200gms:8ml5:0.6gms ; NA not applicable

Table 6: Percentage increase in CS of SS compared to TC

\begin{tabular}{|l|l|l|l|l|l|l|l|}
\hline \multirow{2}{*}{$\begin{array}{l}\text { Curing } \\
\text { in days }\end{array}$} & \multirow{3}{*}{ TC } & \multicolumn{3}{|l|}{ Steel slag } & \multicolumn{3}{l|}{ Increase in compressive strength } \\
\cline { 3 - 8 } & 10 & 20 & 30 & 10 & 20 & 30 \\
\hline 0 & 0 & 0 & 0 & 0 & 0 & 0 & 0 \\
\hline 7 & 29.481 & 42.963 & 29.852 & 32.593 & 45.72864 & 1.256281 & 10.55276 \\
\hline 14 & 32.365 & 44.593 & 35.975 & 40.198 & 37.77846 & 11.15349 & 24.19896 \\
\hline 28 & 38.133 & 47.852 & 48.222 & 55.407 & 25.48563 & 26.45688 & 45.29915 \\
\hline
\end{tabular}


Munnoli, P. M Pattar, T. R. Garawad, J. S.
Table 7: Percentage increase in CS of INSS mix compared to TC

\begin{tabular}{|c|c|c|c|c|c|c|c|}
\hline \multirow{2}{*}{$\begin{array}{l}\text { Curing } \\
\text { in days }\end{array}$} & \multirow[b]{2}{*}{$\mathrm{TC}$} & \multicolumn{3}{|c|}{$\begin{array}{l}\text { Steel slag infused with } \mathrm{NS} \\
\mathrm{N} / \mathrm{mm}^{\wedge} 2\end{array}$} & \multicolumn{3}{|c|}{$\begin{array}{l}\text { Increase in compressive } \\
\text { strength }\end{array}$} \\
\hline & & 10 & 20 & 30 & 10 & 20 & 30 \\
\hline 0 & 0 & 0 & 0 & 0 & 0 & 0 & 0 \\
\hline 7 & 29.481 & 45.037 & 40.222 & 39.852 & 34.539 & 26.703 & 26.022 \\
\hline 14 & 32.365 & 45.926 & 42.123 & 40.198 & 29.527 & 23.165 & 19.484 \\
\hline 28 & 38.133 & 47.704 & 45.926 & 40.889 & 20.062 & 16.968 & 6.739 \\
\hline
\end{tabular}

Table 8: Increase in strength of NSSS mix compared to normal SS mix

\begin{tabular}{|l|l|l|l|}
\hline Curing in days & SS & NSSS & $\%$ Increase \\
\hline \multicolumn{4}{|l|}{$\%$ Increase for $10 \%$} \\
\hline 7 & 42.963 & 15.329 & 64.321 \\
\hline 14 & 44.593 & 23.247 & 47.867 \\
\hline 28 & 47.852 & 38.199 & 20.173 \\
\hline \multicolumn{4}{|l|}{} \\
\hline 7 & $\%$ Increase for $20 \%$ & 82.603 \\
\hline 14 & 29.852 & 5.193 & 54.639 \\
\hline 28 & 35.975 & 16.319 & 25.747 \\
\hline \multicolumn{4}{|l|}{} \\
\hline 7 & 48.222 & 35.806 & 86.769 \\
\hline 14 & $\%$ Increase for $30 \%$ & 69.377 \\
\hline 28 & 32.593 & 4.312 & 49.648 \\
\hline
\end{tabular}

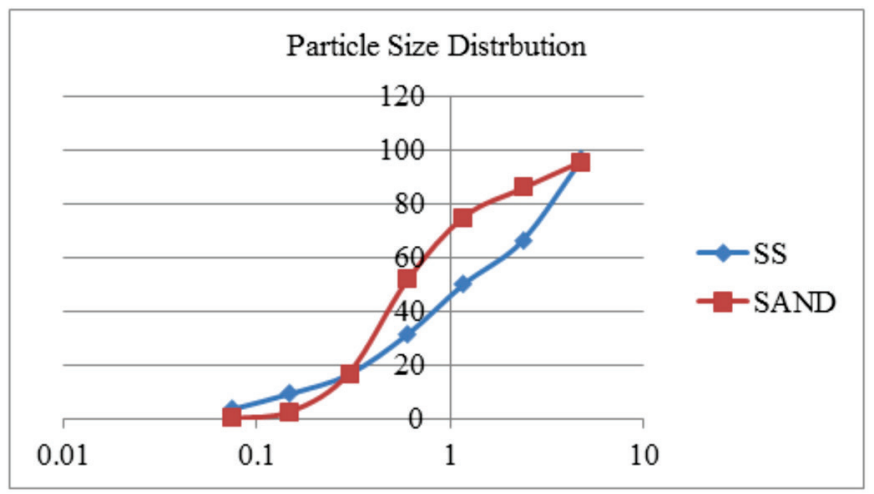

Fig. 1: Particle size distribution of FA and SS 


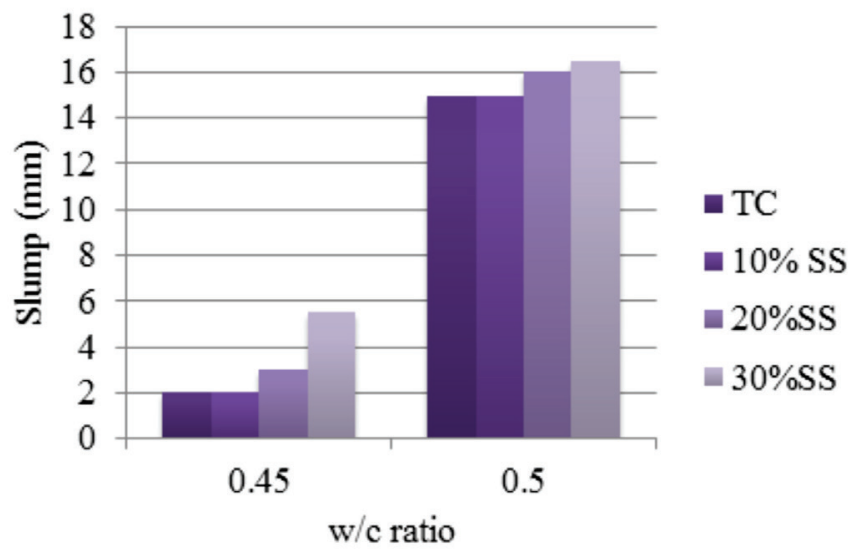

Effect of Partial Replacement of Slag and Nano Silica Infused Slag on Properties of Concrete

Fig. 2: Graph Showing Slump Values For SS

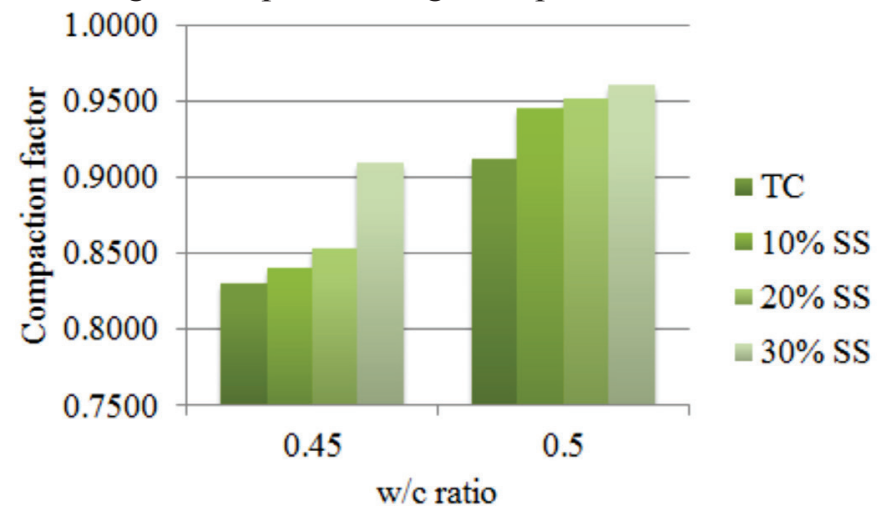

Fig. 3: Graph showing compaction factor of TC and SSC

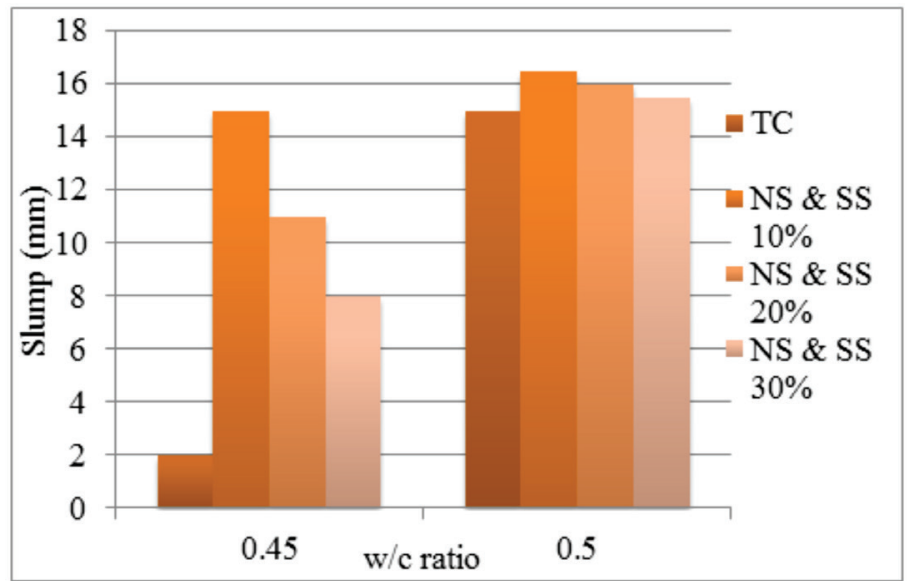

Fig. 4: Comparison of slump values for TC and modified SS in concrete 
Munnoli, P. M

Pattar, T. R.

Garawad, J. S.

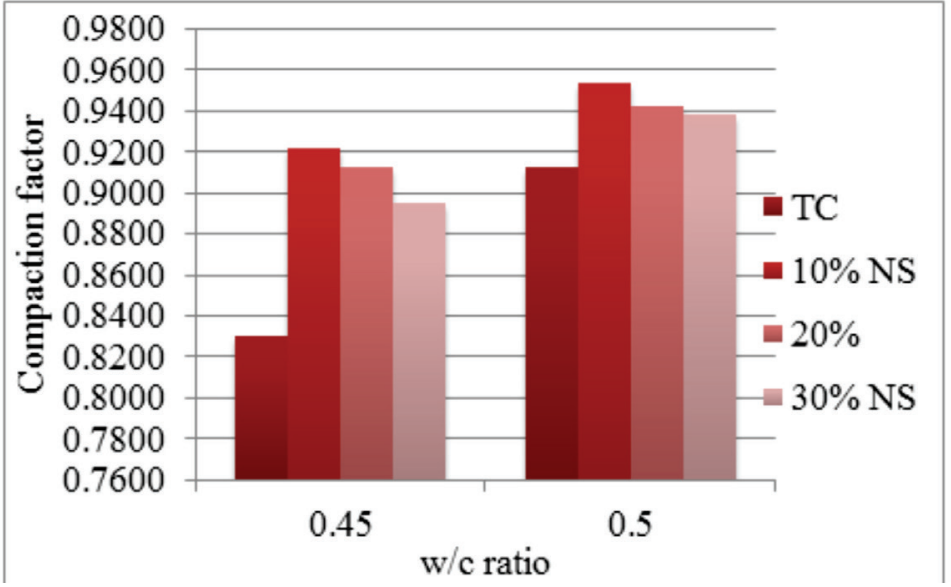

Fig. 5: Compaction factor values for modified SS in concrete

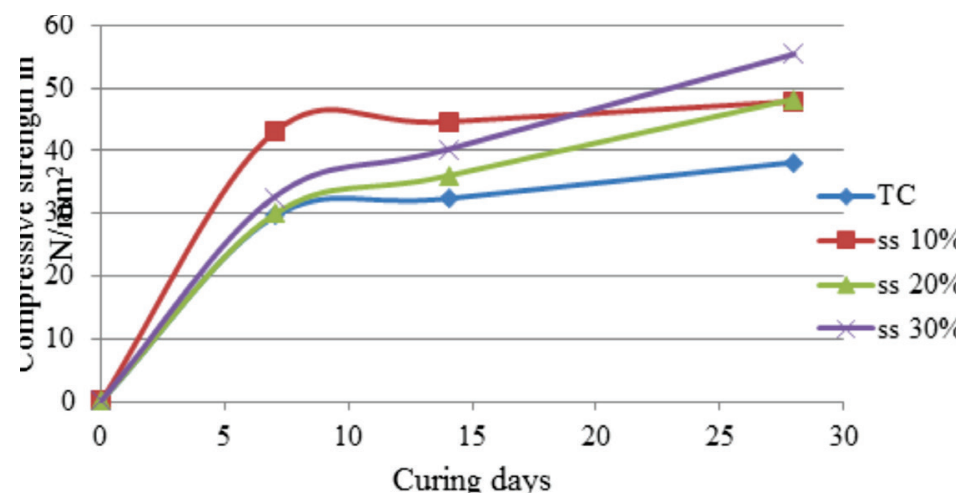

Fig. 6: Variation in CS of TC, $10 \%, 20 \%$ and $30 \%$ mixes

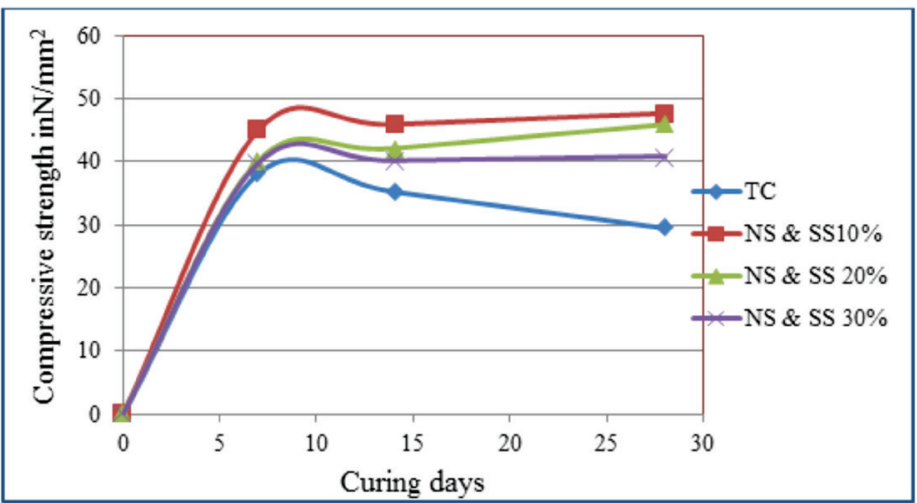

Figure 7: Graph showing variations in CS of TC, $10 \%, 20 \%$ and $30 \%$ NSSS mixes 


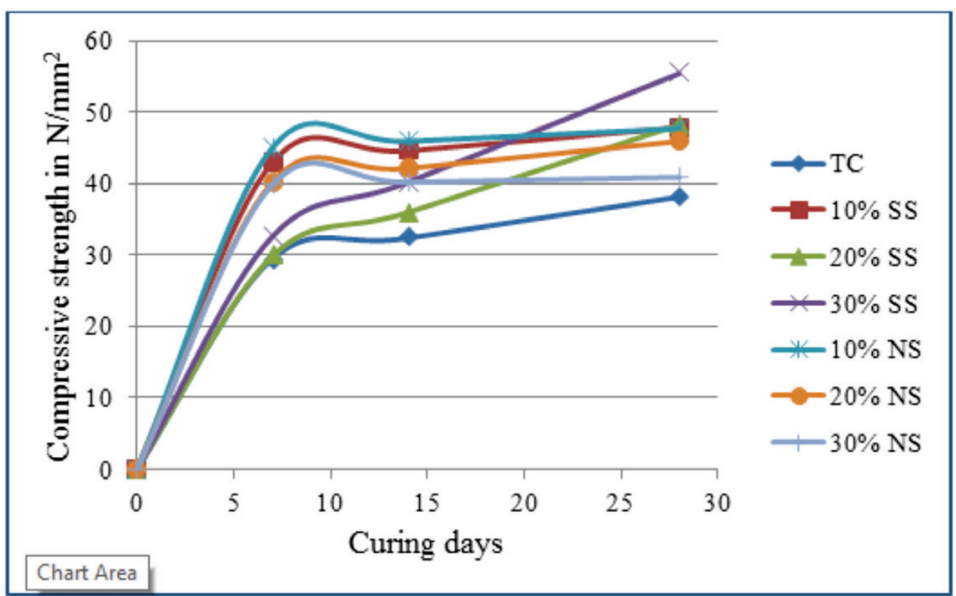

Effect of Partial Replacement of Slag and Nano Silica Infused Slag on Properties of Concrete

Figure 8: Graph showing CS variation for TC, normal SS and NSSS mixes.

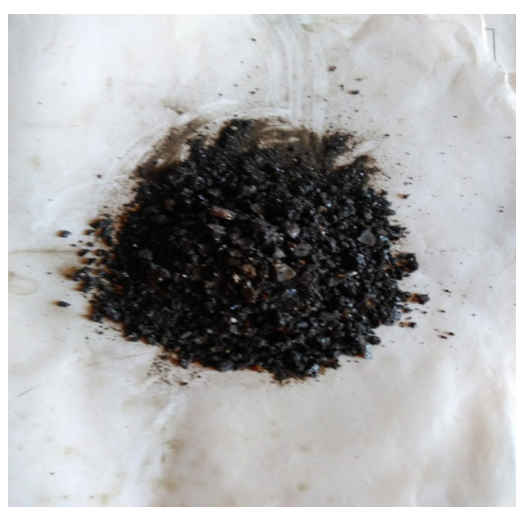

Plate 1: Steel slag

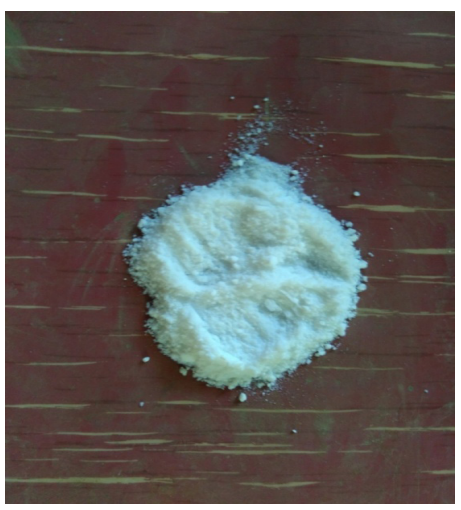

Plate 2: Nano silica

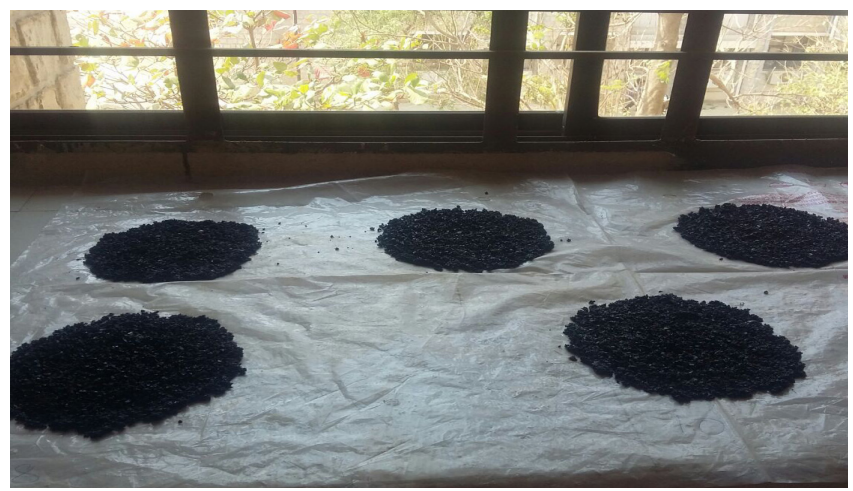

Plate 3: Infused SS kept for air drying. 